\title{
Natural and Experimental Host Range of Sirococcus clavigignenti-juglandacearum
}

\author{
M. E. Ostry and M. Moore, Northern Research Station, 1561 Lindig Avenue, St. Paul, MN 55108
}

\begin{abstract}
Ostry, M. E., and Moore, M. 2007. Natural and experimental host range of Sirococcus clavigignenti-juglandacearum. Plant Dis. 91:581-584.
\end{abstract}

The fungus Sirococcus clavigignenti-juglandacearum causes butternut canker in North America and is not known to kill or seriously affect tree species other than butternut (Juglans cinerea). However, this putative exotic pathogen has been found on branches of black walnut (J. nigra) and heartnut (J. ailantifolia var. cordiformis), raising questions regarding the potential host range of the pathogen and its spread to new areas on tree hosts other than butternut. Results of artificial inoculations of several hardwood species indicated that the pathogen, although not causing lethal cankers, has the ability to colonize and survive in the wood of several genera, including Quercus, Carya, Corylus, Prunus, and Castanea. Several commercially important Persian walnut (J. regia) cultivars tested were moderately or highly susceptible, underscoring the importance of preventing the movement of the pathogen into commercial Juglans plantations in California, where its ability to cause disease and damage trees is unknown. Evidence for the presence of variation in aggressiveness among isolates of S. clavigignenti-juglandacearum was detected based on differences in canker lengths resulting from inoculations with two isolates of the pathogen. In a field test of several previously named butternut cultivars, all were found to be highly susceptible to the disease, calling into question the value of these selections for nut production or future restoration uses.

Butternut (Juglans cinerea) is dying throughout its native range in North America due to infection by the fungus Sirococcus clavigignenti-juglandacearum, described as a new species in 1979 (8). There are no reports of this fungus outside of North America; however, it is believed to be an exotic pathogen (3). Evidence supporting the hypothesis that the origin of the fungus was outside of North America includes the relatively recent first reports of the occurrence of the disease and its documented rapid expansion in North America. The symptoms of the disease are obvious, diagnostic (8), and most likely were not overlooked in the past. In addition, the fungus is easily isolated from active cankers and sporulates profusely, aiding in its identification (8). Similar to the impacts of other introduced pathogens, trees free of the disease or expressing resistance are relatively rare within affected populations of native butternut (14).

The pathogen may have been introduced into the United States by inadvertently moving the fungus on seed of Asian Juglans spp. (14). Japanese walnut (J. ailantifolia) was widely planted from imported

Corresponding author: M. E. Ostry

E-mail: mostry@fs.fed.us

Accepted for publication 30 November 2006.

doi:10.1094/PDIS-91-5-0581

This article is in the public domain and not copyrightable. It may be freely reprinted with customary crediting of the source. The American Phytopathological Society, 2007. seed in the southeastern United States in the early 1900s (2), where butternut survival is now at risk because of past high mortality rates from this canker disease. The fungus can be seedborne on eastern black walnut (J. nigra) and butternut (5). Dissemination of the fungus by insects $(4,6)$ and, presumably, by birds also may contribute to the widespread distribution of the disease among widely dispersed populations of butternut throughout its range in North America.

The most recent United States Department of Agriculture, Forest Service survey data revealed that, overall, in seven Midwestern states, the number of butternut trees in all size classes has decreased by $23 \%$ since 1989 , with decreases in the larger classes ranging from 13 to $100 \%$ measures to conserve butternut with a moratorium on the harvest of healthy butternut in 1992 on state lands (12). Butternut remains a "species of concern" or a "sensitive species" in many states and is a Regional Forester Sensitive Species in the Eastern Region on 13 of the 16 National Forests (15). Butternut was recommended for endangered species status by the Committee on the Status of Endangered Wildlife in Canada in 2003. In Canada, butternut was officially listed as endangered under the Species at Risk Act in 2005 (Species at risk-butternut, online publication through Environment Canada).

Butternut is the only species that has been reported killed by this pathogen. However, other Juglans spp. and hybrids can be affected by $S$. clavigignenti(14). Minnesota was the first state to enact juglandacearum to varying degrees. Eastern black walnut and heartnut (J. ailantifolia var. cordiformis) have been found infected naturally in the field $(10,11)$. Orchard et al. (9) inoculated 10- to 20year-old trees of several Juglans spp. They found that Japanese walnut, heartnut, and hybrids between them and butternut expressed greater resistance than either eastern black walnut or Persian walnut, with the latter species developing the most severe disease.

Nearly the entire U.S. Persian walnut (J. regia) crop is produced in California (1). S. clavigignenti-juglandacearum is not known to be present in California. The potential for $S$. clavigignenti-juglandacearum being introduced into California and its impact on commercially grown Juglans spp. is unknown. However, an existing quarantine on moving Juglans spp. from the eastern United States is in place to avoid the introduction of bunch disease caused by a phytoplasma in the Prunus X-disease group that can affect Juglans spp.

The objective of this study was to determine the susceptibility of Juglans spp. and various other hardwood species, to $S$. clavigignenti-juglandacearum in order to identify potential hosts of the pathogen in forest stands and nurseries that could serve as pathways for the movement of the pathogen on planting stock.

\section{MATERIALS AND METHODS}

Field assessment of butternut cultivars. Several butternut cultivars have been described and some are available as scionwood from collectors and germ plasm repositories (13). From two to four trees of each of 6- to 12-year-old J. cinerea cvs. Bear Creek, Beckwith, Booth, Buckley, Bulman, Chreighton, George Elmer, VanderPoppen, Johnson, Kineyglen, and Painter that were field grafted onto young, wild eastern black walnut saplings in a woodlot near Des Moines, IA were evaluated for symptoms of butternut canker in 2003 and 2006. Numerous severely diseased wild butternut trees were growing among the grafted cultivars. Trees were scored during the dormant season for the presence or absence of stem and branch cankers caused by $S$. clavigignentijuglandacearum.

Propagation of grafted Juglans spp. Details of grafting butternut and other Juglans spp. have been summarized (7). Briefly, bare-root 1-year-old eastern black walnut nursery stock was potted in February 2001 and 2002 with a commercial 
potting mix including composted pine bark. Large-caliper $(>10 \mathrm{~mm})$ rootstock was potted in 10-liter (20-by-46-cm) plastic pots and smaller-caliper rootstock was potted in 3-liter (10-by-36-cm) plastic pots. The plants were placed in a greenhouse at $18^{\circ} \mathrm{C}$ (night) and $24^{\circ} \mathrm{C}$ (day) with no supplemental lighting. Each plant was fertilized with $15 \mathrm{ml}$ of a slow-release 1414-14 commercial fertilizer once and watered as needed for 2 weeks until leaf least 2 weeks before grafting to prevent sap bleeding at the graft site that often causes graft failures. Grafted bare-root $J$. regia 'Chandler' trees received from a flush. They were not watered again for at

California commercial nursery also were potted for testing.

Scionwood from 22 Juglans clones from the United States Department of Agriculture National Crop Germplasm Repository, Davis, CA (Table 1) was grafted onto the eastern black walnut rootstock in 2001 and 2002. The primary types of grafts used were a bud chip graft and a "4 flap" graft (7). Grafts were secured with grafting rubbers and covered with a laboratory film. The temperature in the greenhouse was increased to between 24 and $27^{\circ} \mathrm{C}$. Buds below the graft on the walnut rootstock were removed as they flushed. When the grafts flushed ( 2 to 8 weeks), the plants

Table 1. Juglans selections received from the United States Department of Agriculture National Crop Germplasm Repository, Davis, CA, propagated and inoculated with Sirococcus clavigignenti-juglandacearum

\begin{tabular}{lll}
\hline Accession & \multicolumn{1}{c}{ Species } & \multicolumn{1}{c}{ Origin (cultivar) } \\
\hline 153 & Juglans regia & California (old 636 EN7-1) \\
154 & J. regia & California (old 629 EN5-8) \\
155 & J. regia & Former USSR (Kolobk $\times$ OP) \\
156 & J. regia $\times$ Carya illinoensis & Former USSR (Gibridnyj $\times$ OP) \\
157 & J. regia $\times$ Carya illinoensis & Former USSR (Gibridnyj $\times$ OP) \\
158 & J. regia & Hungary (Type T56 $\times$ OP) \\
159 & J. regia & California (old 648 EN8-8) \\
160 & J. regia & Hungary (Type T56 $\times$ OP) \\
161 & J. regia & Former USSR (Kolobk $\times$ OP) \\
162 & J. regia & California (old 632 EN6-3) \\
163 & J. regia & Hungary (Type T10 $\times$ OP) \\
164 & J. regia & California (old 610 EN2-6) \\
165 & J. regia & Afghanistan (0-70-1307) \\
168 & J. regia & France or China (Payne) \\
170 & J. regia & Oregon (Howe) \\
171 & J. regia & Carpathian (Idaho, Bijou type) \\
173 & J. regia & France (Scharsch Franquette) \\
175 & J. regia & France (Mayette) \\
176 & J. regia & France (Conway Mayette) \\
177 & J. regia & France (Wilson Franquette) \\
180 & J. regia & California (Hartley) \\
181 & J. regia & China (Manregian) \\
\hline
\end{tabular}

Table 2. Successful infection of various inoculated hardwood species and recovery of Sirococcus clavigignenti-juglandacearum from stained wood tissue and callus near wound

\begin{tabular}{|c|c|c|c|c|}
\hline \multirow[b]{2}{*}{ Species } & \multicolumn{3}{|c|}{ Plants infected $(\%)^{\mathrm{u}}$} & \multirow[b]{2}{*}{ Fungus $^{y}$} \\
\hline & Year $1^{\mathrm{v}}$ & Year $2^{\mathrm{w}}$ & Years 3 and $4^{x}$ & \\
\hline Butternut (Juglans cinerea) & 92 & 65 & 100 & Yes \\
\hline Eastern black walnut (Juglans nigra) & 50 & 73 & 100 & Yes \\
\hline Bitternut hickory (Carya cordiformis) & NA & NA & 56 & Yes \\
\hline Pecan (Carya illinoensis) & 67 & 45 & 46 & Yes \\
\hline Shagbark hickory (C. ovata) & 25 & NA & 40 & Yes \\
\hline Black cherry (Prunus serotina) & 0 & NA & NA & $\mathrm{Yes}^{\mathrm{z}}$ \\
\hline White oak (Quercus alba) & 0 & NA & NA & $\mathrm{Yes}^{\mathrm{z}}$ \\
\hline Bur oak (Q. macrocarpa) & 0 & 0 & NA & $\mathrm{Yes}^{\mathrm{z}}$ \\
\hline $\operatorname{Red}$ oak $(Q . r u b r a)$ & 0 & 0 & 0 & $\mathrm{Yes}^{\mathrm{z}}$ \\
\hline Black oak $(Q$. velutina $)$ & 0 & 0 & 0 & $\mathrm{Yes}^{\mathrm{z}}$ \\
\hline American chestnut (Castanea dentata) & NA & NA & 0 & $\mathrm{Yes}^{\mathrm{z}}$ \\
\hline Chinese chestnut (C. mollissima) & NA & NA & 0 & $\mathrm{Yes}^{\mathrm{z}}$ \\
\hline American hazel (Corylus americana) & NA & NA & 0 & $\mathrm{Yes}^{\mathrm{z}}$ \\
\hline Beaked hazel (C. cornuta) & NA & NA & 0 & $\mathrm{Yes}^{\mathrm{z}}$ \\
\hline White ash (Fraxinus americana) & 0 & NA & NA & No \\
\hline Green ash $(F$. pennsylvanica $)$ & 0 & 0 & NA & No \\
\hline
\end{tabular}

" Combined results of inoculations with two separate isolates in each year. NA $=$ not tested.

${ }^{\mathrm{v}}$ Number $=12$ plants of each species inoculated with isolates MN827 and WI889.

${ }^{\mathrm{w}}$ Number $=20$ plants of each species inoculated with isolates MN827 and WI889.

${ }^{\mathrm{x}}$ Number $=$ eight plants of each species inoculated with isolates MN1347 and WI1344 in each year. Results not significantly different $(P=0.701)$.

${ }^{y}$ Fungus recovered; recovery attempted 3 to 5 months post inoculation.

${ }^{\mathrm{z}}$ Fungus recovered from stained wood tissue and callus at or near wound. were watered biweekly and the greenhouse temperature was reduced to between 18 and $24^{\circ} \mathrm{C}$. Supplemental lighting with high-pressure sodium lamps was provided, resulting in at least a 14-h day. An automatic daily watering system was used once plants were well established.

Propagation of hardwood seedlings. Bare-root, dormant 1- to 2-year-old seedlings of several hardwood species (Table 2) were obtained from a commercial nursery in 2002 and 2003. Height and stem caliper ranged from 20 to $60 \mathrm{~cm}$ and 3 to $7 \mathrm{~mm}$, respectively, depending on the species. American chestnut (Castanea dentata), Chinese chestnut (C. mollissima), American hazel (Corylus americana), and beaked hazel $(C$. cornuta) were grown from seed. All plants were potted and grown under greenhouse conditions as described for the grafted Juglans spp.

Preparation of $S$. clavigignentijuglandacearum inoculum. Cultures of $S$. clavigignenti-juglandacearum were isolated from naturally occurring branch cankers on butternut trees growing in Minnesota and Wisconsin. Wood chips were taken from underneath the bark at the margin of an active canker, surface sterilized in a $0.05 \%$ sodium hypochlorite solution for $1 \mathrm{~min}$, rinsed in sterile water, and plated onto potato dextrose agar in petri dishes maintained at $20^{\circ} \mathrm{C}$ in the dark. Identification was confirmed by spores produced in cultures. S. clavigignentijuglandacearum cultures were transferred to fresh malt agar every 2 to 3 months and grown at $20^{\circ} \mathrm{C}$ in the dark.

Inoculation of plants. Juglans spp. The same grafted plants and nursery-run rooted butternut and eastern black walnut seedlings were inoculated in June or July, about 3 months after they flushed, once each year over a 3-year period. In years 1 and 2, each plant was inoculated with isolate MN1339. In year 3, each plant was inoculated with two isolates, MN1347 and WI1344, separately to compare aggressiveness between isolates. In all, 8 to 11 grafted plants of each clone were inoculated. At each inoculation site, a $5-\mathrm{mm}^{2}$ area of bark was removed from the current year's growth of the grafted plants and a 2$\mathrm{mm}^{2}$ plug of a single 3-month-old sporulating culture of $S$. clavigignentijuglandacearum was placed onto the exposed cambium. Inoculated wound sites were wrapped in a laboratory film to minimize drying and contamination. Control inoculations consisted of similar wounds and sterile agar plugs. Plants were placed randomly on a greenhouse bench. The greenhouse temperature was maintained between 18 and $24^{\circ} \mathrm{C}$. Supplemental lighting was provided using high-pressure sodium lamps. Plants were watered as necessary.

Hardwood seedlings. Each seedling was inoculated in June or July after 2 to 3 months of growth (5 months for the seed- 
grown plants) with two separate isolates on the current year's wood each year over a 4year period as described above. Isolates MN827 and WI889 were used in years 1 and 2 and isolates WI1344 and MN1347 were used in years 3 and 4 . Between 8 and 20 plants of each species were inoculated each year and placed randomly on a greenhouse bench. All species were not tested in each year. The greenhouse temperature was maintained between 18 and $24^{\circ} \mathrm{C}$. Supplemental lighting was provided using high-pressure sodium lamps. Plants were watered as necessary.

Re-isolation of the fungus. At 3 to 5 months after inoculation, tissue samples were taken from canker margins and callus tissue at or near the wound site on selected symptomatic and nonsymptomatic plants, respectively. Fungal isolation and identification were done as described previously for inoculum preparation.

Scoring and statistical analysis. Plants were examined for symptom development 4 weeks after inoculation and the canker length, minus the original wounded area, was recorded. Canker length means were analyzed by Pearson correlation and separated according to Fisher's protected least significant difference. Analysis of variance of canker length means was computed to determine the effects of clone or species, isolate, and year, and $\chi^{2}$ tests were used to determine the effects of clone or species, isolate, and year on the number of plants becoming infected. Data were analyzed using Systat 9.0 (SPSS Inc. Chicago).

\section{RESULTS}

Field assessment of butternut cultivars. Multiple branch and mainstem cankers and crown dieback resulting from girdling cankers were common on all individuals of each cultivar except Booth (no dieback) and Painter, for which one of the two trees was free of visible cankers (data not shown).

Response of Juglans spp. Results from years 1 and 2 (Table 3 ) were similar $(P=$ $0.141)$ and were combined for analyses. Infection percentages among plants of individual Juglans clones ranged from 62 to $100 \%$ and there were significant differences $(P<0.001)$ in canker lengths among clones. The results from year 3 (Table 4 ) were significantly different $(P<0.001)$ than the previous 2 years and were analyzed separately. The difference in results may be due to the significantly larger $(P<$ $0.001)$ cankers produced by isolate MN1347 than by MN1339 or WI1344. However, the relative ordering of the clones based on susceptibility to the isolates was similar (Tables 3 and 4). The most similar ordering was obtained using isolates MN1347 and WI1344 $(r=0.830)$. Many of the $J$. regia clones (Table 1 ) had greater mean canker lengths than either butternut or eastern black walnut, and the commercial J. regia cultivars (cvs. 180,
168, 173, and Chandler) were among the most severely diseased (Tables 3 and 4).

Response of hardwood species. Response of various hardwood species to inoculation ranged from complete callusing of wounds to bark collapse and canker development. The proportion of infected trees of each species varied by year (Table 2 ), but isolate had no significant effect $(P$ $=0.634$ ) on the proportion of infected trees and results within each year were combined. White ash (Fraxinus americana) and green ash ( $F$. pennsylvanica), American hazel (C. americana) and beaked hazel (C. cornuta), black cherry (Prunus serotina), and most oak (Quercus) and chestnut (Castanea) species developed abundant callus over inoculated and control wounds alike. In contrast, little or no callus developed around the inoculated wounds of species within genera related to Juglanspecan (Carya illinoensis), bitternut hickory (C. cordiformis), and shagbark hickory $(C$. ovata). Bark collapse was evident at the margin of inoculated wounds on these species but control wounds were well callused.

Recovery of $S$. clavigignentijuglandacearum. The fungus was recovered in pure culture up to 5 months after inoculation from nearly all samples of inoculated plants with visible canker symptoms. In addition, the fungus also was recovered from the callus and stained wood tissue at or near the wounded site from species that were inoculated with the fungus but did not exhibit canker symptoms and developed callus at wound sites-white oak (Quercus alba), bur oak
(Q. macrocarpa), red oak ( $Q$. rubra), black oak $(Q$. velutina), black cherry $(P$. serotina), American chestnut (Castanea dentata), Chinese chestnut (C. mollissima), American hazel, and beaked hazel (Table 2). No symptoms developed at control wound sites on any species and most wounds were well callused.

\section{DISCUSSION}

The butternut cultivars we examined in the field originally were selected by growers for propagation based on their nut crop potential, specifically large nut size, before the known occurrence of butternut canker. None of the cultivars have been widely planted. Although a limited number of trees was examined in only one location, the apparent high susceptibility of most of these trees calls into doubt their potential value for nut production, conservation, or restoration purposes. Caution should be exercised in propagating and distributing these cultivars to areas where butternut canker is known to be present.

Persian walnut clones we tested in the greenhouse were highly susceptible to $S$. clavigignenti-juglandacearum, similar to the findings from field tests of other Persian walnut selections described by Orchard and others (9). Our lack of knowledge as to the potential of the pathogen to survive and cause disease in California indicates that continued caution should be exercised to prevent any Juglans material collected, from within the range of butternut, from being moved into California walnut production areas.

Table 3. Results of inoculations of Juglans spp. and cultivars with a single isolate of Sirococcus clavigignenti-juglandacearum sorted by ascending proportion of infected plants ${ }^{z}$

\begin{tabular}{lccc}
\hline Accession & $\begin{array}{c}\text { Plants } \\
(\mathbf{n o} .)\end{array}$ & $\begin{array}{c}\text { Infected } \\
(\%)\end{array}$ & $\begin{array}{c}\text { Mean canker length } \\
(\mathbf{m m})\end{array}$ \\
\hline 163 Juglans regia & 13 & 62 & $3.0 \mathrm{abc}$ \\
162 J. regia & 9 & 67 & $1.5 \mathrm{ab}$ \\
J. nigra & 13 & 69 & $1.3 \mathrm{ab}$ \\
J. cinerea & 20 & 81 & $1.0 \mathrm{ab}$ \\
157 J. regia $\times$ Carya illinoensis & 17 & 81 & $1.2 \mathrm{ab}$ \\
153 J. regia & 14 & 86 & $1.5 \mathrm{ab}$ \\
165 J. regia & 9 & 89 & $4.5 \mathrm{~cd}$ \\
164 J. regia & 11 & 90 & $1.7 \mathrm{abc}$ \\
171 J. regia & 11 & 90 & $3.6 \mathrm{bcd}$ \\
160 J. regia & 10 & 91 & $2.4 \mathrm{abcd}$ \\
173 J. regia & 12 & 92 & $3.6 \mathrm{bcd}$ \\
154 J. regia & 15 & 93 & $2.4 \mathrm{abcd}$ \\
156 J. regia $\times$ C. illinoensis & 16 & 94 & $1.7 \mathrm{abc}$ \\
161 J. regia & 11 & 100 & $1.7 \mathrm{abc}$ \\
181 J. regia & 9 & 100 & $1.8 \mathrm{abc}$ \\
177 J. regia & 12 & 100 & $3.6 \mathrm{~cd}$ \\
175 J. regia & 17 & 100 & $3.7 \mathrm{~cd}$ \\
158 J. regia & 13 & 100 & $4.5 \mathrm{cde}$ \\
155 J. regia & 12 & 100 & $4.6 \mathrm{cde}$ \\
Chandler' J. regia & 31 & 100 & $4.8 \mathrm{de}$ \\
176 J. regia & 13 & 100 & $5.2 \mathrm{de}$ \\
159 J. regia & 15 & 100 & $7.0 \mathrm{ef}$ \\
168 J. regia & 10 & 100 & $7.2 \mathrm{ef}$ \\
170 J. regia & 11 & 100 & $8.6 \mathrm{f}$ \\
180 J. regia & 13 & 100 & $9.5 \mathrm{f}$ \\
\hline Cor & & &
\end{tabular}

${ }^{\mathrm{z}}$ Combined results of years 1 and 2. Plants were inoculated with isolate MN1339. Values followed by the same letter do not differ significantly according to Fisher's least significant difference test $(P=$ $0.05)$. 
Table 4. Results of inoculations of Juglans with two separate Sirococcus clavigignenti-juglandacearum isolates sorted by ascending mean canker lengths

\begin{tabular}{|c|c|c|c|}
\hline Accession $^{y}$ & Plants (no.) & Infected (\%) & Mean canker length $(\mathbf{m m})^{\mathrm{z}}$ \\
\hline \multicolumn{4}{|l|}{ Isolate MN1347-1 } \\
\hline Juglans cinerea & 9 & 100 & $3.7 \mathrm{a}$ \\
\hline 153 & 10 & 100 & $3.8 \mathrm{a}$ \\
\hline 154 & 8 & 100 & $4.6 \mathrm{ab}$ \\
\hline 161 & 8 & 100 & $5.5 \mathrm{abc}$ \\
\hline 162 & 8 & 100 & $5.9 \mathrm{abc}$ \\
\hline 157 & 9 & 100 & $6.7 \mathrm{abc}$ \\
\hline 177 & 8 & 100 & $7.0 \mathrm{abc}$ \\
\hline 181 & 8 & 100 & $7.1 \mathrm{abc}$ \\
\hline 171 & 8 & 100 & $7.6 \mathrm{abc}$ \\
\hline 173 & 10 & 100 & $7.7 \mathrm{abc}$ \\
\hline 170 & 8 & 100 & $7.8 \mathrm{abd}$ \\
\hline 164 & 9 & 100 & $8.0 \mathrm{bcd}$ \\
\hline 163 & 9 & 100 & 8.1 bcde \\
\hline J. nigra & 10 & 100 & 8.4 bcde \\
\hline 165 & 9 & 100 & $8.6 \mathrm{bcde}$ \\
\hline 'Chandler' & 11 & 100 & $8.7 \mathrm{cde}$ \\
\hline 180 & 8 & 100 & $8.9 \mathrm{cde}$ \\
\hline 160 & 10 & 100 & $9.0 \mathrm{cde}$ \\
\hline 156 & 10 & 100 & $9.2 \mathrm{de}$ \\
\hline 158 & 10 & 100 & $10.3 \mathrm{def}$ \\
\hline 159 & 11 & 100 & $10.4 \mathrm{def}$ \\
\hline 155 & 10 & 100 & $11.0 \mathrm{def}$ \\
\hline 175 & 10 & 100 & $11.4 \mathrm{def}$ \\
\hline 176 & 9 & 100 & $12.2 \mathrm{ef}$ \\
\hline 168 & 8 & 100 & $13.5 \mathrm{f}$ \\
\hline \multicolumn{4}{|l|}{ Isolate WI1344-3 } \\
\hline 153 & 10 & 100 & $2.2 \mathrm{abc}_{\mathrm{z}}$ \\
\hline 154 & 8 & 100 & $2.5 \mathrm{abc}$ \\
\hline 161 & 8 & 100 & $2.9 \mathrm{abc}$ \\
\hline 181 & 8 & 100 & $3.0 \mathrm{abc}$ \\
\hline 157 & 9 & 100 & $3.2 \mathrm{abc}$ \\
\hline 171 & 8 & 75 & $3.3 \mathrm{abc}$ \\
\hline 164 & 9 & 100 & $3.4 \mathrm{abc}$ \\
\hline J. nigra & 10 & 100 & $3.6 \mathrm{abcd}$ \\
\hline J. cinerea & 8 & 88 & 3.9 abcd \\
\hline 162 & 8 & 100 & $4.0 \mathrm{abcd}$ \\
\hline 'Chandler' & 11 & 100 & $4.0 \mathrm{abcd}$ \\
\hline 163 & 9 & 100 & $4.3 \mathrm{abcd}$ \\
\hline 177 & 8 & 100 & $4.8 \mathrm{bcd}$ \\
\hline 165 & 9 & 100 & $4.8 \mathrm{bcd}$ \\
\hline 173 & 10 & 100 & $4.8 \mathrm{bcd}$ \\
\hline 160 & 9 & 100 & $4.9 \mathrm{bcd}$ \\
\hline 175 & 11 & 100 & $4.9 \mathrm{bcd}$ \\
\hline 156 & 10 & 100 & 5.1 bcde \\
\hline 158 & 10 & 100 & 5.5 bcde \\
\hline 180 & 7 & 100 & $5.7 \mathrm{cdef}$ \\
\hline 170 & 8 & 100 & $6.1 \mathrm{def}$ \\
\hline 155 & 10 & 100 & $7.1 \mathrm{def}$ \\
\hline 159 & 11 & 100 & $7.4 \mathrm{def}$ \\
\hline 176 & 9 & 100 & $8.4 \mathrm{fg}$ \\
\hline 168 & 8 & 100 & $10.5 \mathrm{~g}$ \\
\hline
\end{tabular}

y 'Chandler' $=$ J. regia, 156 and $157=$ J. regia $\times$ C. illinoensis, and other numbered cultivars $=$ J. regia.

${ }^{z}$ Values with the same letter do not differ significantly according to Fisher's least significant difference test $(P=0.05)$.

All isolates used in these tests were pathogenic on the same Juglans clones and species. However, the differences in mean canker length on trees caused by inoculations of Juglans spp. with two isolates of the pathogen is the first evidence that suggests there may be variation in aggressiveness among isolates of $S$. clavigignentijuglandacearum under similar environmental conditions.

Although butternut is the only species killed by butternut canker, evidence from been reported; however, close examination of other tree species growing adjacent to affected butternut may be warranted.

\section{LITERATURE CITED}

1. Beede, R. H., and Hasey, J. K. 1998. The history of the walnut in California. Pages 8-15 in: Walnut Production Manual. D. E. Ramos, ed. Publ. 3373. University of California, Division of Agriculture and Natural Resources, Oakland.

2. Bixby, W. G. 1919. The butternut and the Japan walnut. Am. Nut J. 10:76-83.

3. Furnier, G. R., Stolz, A. M., Raka, M. M., and Ostry, M. E. 1999. Genetic evidence that butternut canker was recently introduced into North America. Can. J. Bot. 77:783-785.

4. Halik, S., and Bergdahl, D. R. 2002. Potential beetle vectors of Sirococcus clavigignentijuglandacearum on butternut. Plant Dis. 86:521-527.

5. Innes, L. 1997. Sirococcus clavigignentijuglandacearum on butternut and black walnut fruit. Pages 129-132 in: Foliage, Shoot and Stem Diseases of Trees: Proc. IUFRO WP 7.02.02 Meeting. G. Laflamme, J. A. Bérubé, and R. C. Hamelin, eds. Natural Resources Canada, Canadian Forest Service, Laurentian Forestry Centre, Quebec City, Quebec, Canada

6. Katovich, S. A., and Ostry, M. E. 1998. Insects associated with butternut and butternut canker in Minnesota and Wisconsin. Great Lakes Entomol. 31:97-108.

7. Moore, M. J., and Ostry, M. E. Grafting butternut: the challenge of conserving a threatened tree. North. Nut Grow. Assoc. Annu. Rep. In press.

8. Nair, V. M. G., Kostichka, C. J., and Kuntz, J. E. 1979. Sirococcus clavigignenti-juglandacearum: An undescribed species causing canker on butternut. Mycologia 71:641-646.

9. Orchard, L. P., Kuntz, J. E., and Kessler, K. J. 1982. Reactions of Juglans species to butternut canker and implications for disease resistance. Pages 27-31 in: Black Walnut for the Future: Gen. Tech. Rep. NC-74. U. S. Dep. Agric. For Serv. North Central For. Exp. Stn., St. Paul, MN.

10. Ostry, M. E. 1997. Sirococcus clavigignentijuglandacearum on heartnut (Juglans ailanthifolia var. cordiformis). Plant Dis. 81:1461.

11. Ostry, M. E., Katovich, S., and Anderson, R. L. 1997. First report of Sirococcus clavigignentijuglandacearum on black walnut. Plant Dis. 81:830.

12. Ostry, M. E., Mielke, M. E., and Skilling, D. D. 1994. Butternut-strategies for managing a threatened tree. Gen. Tech. Rep. NC-165. U. S Dep. Agric. For. Serv. North Central For. Exp. Stn., St. Paul, MN.

13. Ostry, M. E., and Pijut, P. M. 2000. Butternut: an underused resource in North America. HortTechnology 10:302-306.

14. Ostry, M. E., and Woeste, K. 2004. Spread of butternut canker in North America, host range, evidence of resistance within butternut populations and conservation genetics. Pages 114-120 in: Black Walnut in a New Century. Proc. 6th Walnut Council Res. Symp., Lafayette, IN. C. H. Michler, P. M. Pijut, J. Van Sambeek, M Coggeshall, J. Seifert, K. Woeste, and R. Overton, eds. Gen. Tech. Rep. NC-243. U. S. Dep. Agric. For. Serv. North Central For. Exp. Stn., St. Paul, MN

15. Schultz, J. 2003. Conservation assessment for butternut or white walnut (Juglans cinerea) L. U. S. Dep. Agric. For. Serv. Eastern Region, Milwaukee, WI 